\title{
Gradients in dimethylsulfide, dimethylsulfonio- propionate, dimethylsulfoxide, and bacteria near the sea surface
}

\author{
Hendrik J. Zemmelink ${ }^{1,2, *}$, Leah Houghton ${ }^{1}$, Stefan M. Sievert ${ }^{1}$, \\ Nelson M. Frew ${ }^{1}$, John W. H. Dacey ${ }^{1}$ \\ ${ }^{1}$ Woods Hole Oceanographic Institution, Woods Hole, Massachusetts 02543, USA \\ ${ }^{2}$ Present address: School of Environmental Sciences, University of East Anglia, Norwich NR4 7TJ, UK
}

\begin{abstract}
Gradients of dimethylsulfide (DMS), dimethylsulfoniopropionate (DMSP), dimethylsulfoxide (DMSO), and bacterial numbers and diversity from the surface microlayer to $500 \mathrm{~cm}$ depth were assessed in coastal waters surrounding the Martha's Vineyard Coastal Observatory, Massachusetts, USA. Microlayer samples were collected with a surface skimmer: a partially submerged, rotating glass cylinder ('drum') that allows the collection of a thin layer of water by adherence to the drum. A depletion of DMS towards the water surface $(10 \mathrm{~cm})$ was found at all sampling days, with largest gradients during rough sea surface conditions. The steep gradients show that gas fluxes and transfer velocities, based on the concentration disequilibrium between the water and the atmosphere, need to be based on near surface gas concentration values. Elevated DMSP, DMSO concentrations and bacterial numbers were found at the sea surface during calm conditions. Although degassing and photooxidation on the skimmer will bias the microlayer data, the results indicate stratification of DMSP, DMSO and bacteria during periods of smooth sea surface conditions.
\end{abstract}

KEY WORDS: Marine sulfur - Bacteria - Depth profiles · Microlayer sampling · Coastal waters · $\mathrm{DMS} \cdot \mathrm{DMSP} \cdot \mathrm{DMSO}$

\section{INTRODUCTION}

Ocean-atmosphere interactions and feedback mechanisms are key processes that need to be quantified in order to understand the role of the oceans in atmospheric chemistry and global climate. The biogenic gas dimethylsulfide (DMS) and its precursor dimethylsulfoniopropionate (DMSP) have been a focus of research since Lovelock et al. (1972) reported that DMS emissions from the oceans could possibly close the global sulfur budget.

Lovelock et al. (1972) showed, 30 yr ago, that the biogenic gas DMS was present in surface waters throughout the Atlantic Ocean. Since then, DMS has been found to be ubiquitous in the surface waters of the oceans and in concentrations far in excess of the concentration expected it were in equilibrium with the atmosphere (e.g.
Kettle et al. 1999). The implications from this and other studies suggest that there is an efflux of DMS from the ocean to the atmosphere and that DMS could have a major impact on atmospheric chemistry. Shaw (1983) and Charlson et al. (1987) suggested that atmospheric oxidation products of DMS are part of one of the major feedback mechanisms linking the global biosphere and climate. Indeed, empirical evidence for a DMS-driven negative climate feedback has been found (e.g. Ayers \& Gillett 2000, Sciare et al. 2000).

DMS and its oxidation products affect atmospheric chemistry in various ways (Andreae \& Crutzen 1997). Once emitted from the oceans, DMS is subject to oxidation by free radicals, such as $\mathrm{OH}^{-}$and $\mathrm{NO}_{3}{ }^{+}$, to form a variety of products including methane sulfonic acid and sulfur dioxide, part of which in turn is oxidized to form non-sea-salt sulfate, which can influence the 
earth's radiation budget. Quantifying the contribution of DMS to the atmospheric sulfur burden remains a major problem, even with the current understanding of the dynamics of DMS in the atmosphere. Estimates of the magnitude of the sea-to-air flux range from 15 to $33 \mathrm{Tg} \mathrm{S} \mathrm{yr}^{-1}$ (Kettle \& Andreae 2000). The main reasons for the uncertainty are: (1) the sea-air gas transfer velocities, and (2) the temporal and spatial variability of DMS in the surface ocean (Kettle \& Andreae 2000).

Estimates of sea-air gas transfer velocity have focused on remote sensing of the sea surface roughness as an improvement over wind-speed parameterization (e.g. Glover et al. 2002). In addition, short-term variability in gas transfer has been studied by field measurements of $\mathrm{CO}_{2}$ fluxes (Jacobs et al. 1999, McGillis et al. 2001) and, more recently, by measurements of the DMS flux itself (Zemmelink et al. 2002, 2004a,b, Hintsa et al. 2004). Transfer velocities $\left(k_{\text {gas }}\right)$ are in these studies calculated as $k_{\text {gas }}=$ Flux $/ \Delta C$ (where $\Delta C$ is the air/water disequilibrium of the relevant gas). Such studies provide insight into the variability of gas transfer velocities in space and time, which subsequently can be used to calibrate and construct models of gas transfer (e.g. Wanninkhof \& McGillis 1999).

Fluxes and transfer velocities are computed from the air/water disequilibrium, using water that is sampled at some distance from the surface. Kieber et al. (1996) calculated that atmospheric ventilation is the predominant removal pathway in the upper $1 \mathrm{~m}$ of the water column, which implies a strong gradient of DMS, with smaller concentrations at the surface than in deeper water. In contrast, Yang (1999) observed an enrichment of DMS at the surface microlayer. Both observations illustrate that subsurface water samples may not contain equal concentrations of DMS at the boundary layer between the water and the overlying air.

DMS in seawater is dynamic, with turnover times measured in hours and with biological and photochemical sinks in addition to flux to the atmosphere. The understanding of factors that regulate the near surface concentration of DMS (and of any other gas) in time and space is a significant and specific problem that hampers an accurate quantification of the sea-toair flux. Most studies have focused on the biochemistry of DMS at some depth in the water column (e.g. Stefels 2000). The concentrations of DMS are linked to DMSP, and dimethylsulfoxide (DMSO), which are governed by complex biological interactions such as nutrient availability, primary production, senescence of phytoplanktonic DMSP-carriers, zooplankton grazing and bacterial degradation (see Groene 1995 for review). In addition, the DMS-producing communities and chemical processes (e.g. the loss of DMS through photolysis) are affected by physical dynamics of the surface layer (e.g. turbulence) and by meteorological forcing such as total solar radiation, UV intensity (and spectrum), and wind speed. Despite extensive work on the relevant physical parameters that affect the surface microlayer, the origin and dynamics of microbiological communities in this layer are less well studied.

The sea surface microlayer could contain elevated levels of nutrients and bacteria compared to the underlying bulk water (Kjelleberg et al. 1979, Plusquellec et al. 1999, Yang 1999, Yang et al. 2001). Horizontal and vertical distribution of bacteria may be dependent on spreading rates of surfactants, wind-induced surface drift and mixing rather than on bulk water circulation (Hale \& Mitchell 1997).

Although the biogeochemistry of DMS and related sulfur compounds has been studied in the upper $1 \mathrm{~m}$ of the water column (Kieber et al. 1996, Lee et al. 1999), it has proved difficult to sample closer to the boundary layer and study DMS dynamics at the surface microlayer, which directly influences the magnitude of fluxes.

A popular method to sample the sea surface is to withdraw a film of water from the surface by adherence to a screen or plate (Yang 1999, Yang et al. 2001, Zhang et al. 1998, 2003). However, Yang et al. (2001) suggested that withdrawal speed and grid size do affect the sampled volume and that the microlayer sample is potentially diluted with subsurface water from various depths. This implies that samples collected by screens and plates are more likely to represent an integrated water column over the sampling depth. In addition, the withdrawal speed is difficult to control (especially from a moving platform), which could affect the reproducibility of results. Carlson et al. (1988) and Frew et al. (2002) used a surface microlayer skimmer to study the occurrence of surfactants at the sea surface. The skimmer is a partially submerged, rotating glass cylinder that collects a thin layer of water of about $50 \mu \mathrm{m}$ thickness by adherence to the drum. Sampling depth and speed are relatively easy to control, thus allowing the collection of constant volumes of water.

The primary objective of this study was to examine the distribution and variability of DMS, its precursor DMSP and its oxidation product DMSO in the upper water column by sampling the water with a surface skimmer. A secondary goal for the project was to extend the use of the skimmer to study the microbial community composition as a function of depth.

\section{MATERIALS AND METHODS}

Study area. Water and meteorological data were collected around the Martha's Vineyard Coastal Observatory (MVCO) at $41^{\circ} 20.996^{\prime} \mathrm{N}, 70^{\circ} 31.606^{\prime} \mathrm{W}$ during $1 \mathrm{~d}$ 
cruises on 14, 15, 18, 25 and 26 August 2003. Water depth around the MVCO is $15 \mathrm{~m}$. Wind speed $\left(\mathrm{m} \mathrm{s}^{-1}\right)$ was measured by a Solent Model R3, and air temperature $\left({ }^{\circ} \mathrm{C}\right.$ ) by the VaiPTU (Vaisala) at $12.5 \mathrm{~m}$ above mean sea level. Wave height $(\mathrm{m})$ and seawater temperature $\left({ }^{\circ} \mathrm{C}\right)$ were calculated from an RD Instruments acoustic Doppler current profiler at $10 \mathrm{~m}$ depth. Solar radiation $\left(\mathrm{W} \mathrm{m} \mathrm{m}^{-2}\right.$ ) was measured using an Eppley Model PSP (Precision Spectral Pyranometer) deployed from the marine shore laboratory. The presented meteorological data are averages over the duration of the sampling period (from 14:00 to 15:00 h) plus $1 \mathrm{~h}$ prior to the sampling period. More detailed and time series of meteorological data can be found at http:// mvcodata.whoi.edu/cgi-bin/mvco/mvco.cgi.

Microlayer sampling. The sea surface was sampled from 14:00 to 15:00 h with a surface microlayer skimmer consisting of a rotating glass cylinder $(15 \mathrm{~cm}$ in diameter) partially submerged to $5 \mathrm{~cm}$ depth (Frew et al. 2002). The cylinder rotated at a speed of 23 rotations $\mathrm{min}^{-1}$ while collecting a thin layer of water by viscous retention. Adhering water was wiped off the cylinder and collected in a $100 \mathrm{ml}$ vial in about $1.5 \mathrm{~s}$. The water was subsequently transferred at an $80 \mathrm{ml}$ $\mathrm{min}^{-1}$ flow (using peristaltic pumps) to a 4.41 darkened glass bottle. A second sampling line was mounted near the skimmer and supplied subsurface water from $10 \mathrm{~cm}$ depth (at $80 \mathrm{ml} \mathrm{min}^{-1}$ flow). The drum and second sampling line were supported by a small catamaran mounted within a larger remote-controlled catamaran cruising at a speed of $1 \mathrm{~m} \mathrm{~s}^{-1}$. Samples from $500 \mathrm{~cm}$ depth were collected with Niskin bottles and immediately transferred to the darkened glass bottles.

Typically, 4.41 samples of all depths were collected over a 60 min period and (1) brought back to the laboratory for immediate analysis (DMS), or (2) treated for overnight reduction and next-day analysis (DMSO), or (3) stored for later analysis (DMSP) within $48 \mathrm{~h}$.

Skimmer artifact. A potential artifact introduced by the skimmer is the loss of volatile compounds on the rotating drum. This loss is largely determined by gas solubility characteristics, water temperature and wind speed at the surface of the skimmer, and would lead to erroneous depth profiles of gases. Gases with different solubility (DMS and carbondisulfide, $\mathrm{CS}_{2}$ ) were sampled at different wind speeds to gain insight into the skimmer-introduced artifact.

A $10 \mathrm{nM}$ solution of DMS and a $15 \mathrm{nM}$ solution of $\mathrm{CS}_{2}$ were prepared in an $80 \mathrm{l}$ aquarium. The solution was thoroughly mixed at $400 \mathrm{l} \mathrm{h}^{-1}$ by a conventional aquarium pump. The outlet from the pump created an upwelling flow from the bottom of the aquarium to the surface in order to inhibit the formation of a depleted surface layer. The surface was sampled by the skimmer as described above. A second sample was col- lected from $3 \mathrm{~cm}$ depth through $0.64 \mathrm{~cm}$ o.d. stainless steel tubing at $0.5 \mathrm{~cm}$ distance from the cylinder.

By creating the upwelling flow and taking water from approximately the same location in the aquarium, it was assumed that any difference between the 2 samples would be due to a skimmer-related artifact. A fan was used to generate wind over the aquarium and the skimmer to simulate the possible effects of wind in the field. Water was sampled at wind speeds of $0,1,2$, and $3 \mathrm{~m} \mathrm{~s}^{-1}$, while air and water temperature were kept constant at $20^{\circ} \mathrm{C}$.

The applicability of the skimmer for sampling bacteria was tested with a culture of Escherichia coli. A mixture of $6.5 \times 10^{6}$ cells $\mathrm{ml}^{-1}$ was prepared in the aquarium and sampled as described above. Cells were stained with acridine orange after collection and counted under a Zeiss epifluorescence microscope. The ratio between cell numbers in water collected with the skimmer and cell numbers in water collected by the tubing gave an idea of the effectiveness of the skimmer for the collection of small particles and bacteria.

Analysis of DMS and major sulfur compounds. DMS and $\mathrm{CS}_{2}$ were stripped from $4 \mathrm{ml}$ subsamples by vigorous bubbling with $\mathrm{N}_{2}$ at about $120 \mathrm{ml} \mathrm{min} \mathrm{m}^{-1}$ for $6 \mathrm{~min}$. Subsequently, the compounds were trapped in cold $\left(-15^{\circ} \mathrm{C}\right)$ Tenax in $0.64 \mathrm{~cm}$ o.d. glass-lined Silicosteel tubing. DMS and $\mathrm{CS}_{2}$ were desorbed into a gas chromatograph (GC) by heating to approximately $180^{\circ} \mathrm{C}$, and analyzed by a Seivers chemiluminiscence detector (detection limit $5 \times 10^{-13} \mathrm{~mol}$ ) after separation on Chromosorb 330 (Supelco). Unfiltered and gravity-filtered (Whatman GF/F) water was used for the analysis of DMS. There was no significant difference between DMS concentrations from filtered and unfiltered water samples ( $\mathrm{n}=12, \mathrm{p}<0.05)$, and the average of both treatments was used for further analysis.

Samples were divided into $50 \mathrm{ml}$ glass reaction vials for subsequent analysis of total DMSP and DMSO. $\mathrm{NaOH}$ was added to each DMSP sample to bring the $\mathrm{OH}^{-}$concentration to $1 \mathrm{~N}$ : this catalyzes the conversion of DMSP to acrylic acid and DMS. Samples were capped with Teflon-lined serum stoppers after addition of $\mathrm{OH}^{-}$and stored at $4{ }^{\circ} \mathrm{C}$ until analysis.

Our procedure for DMSO analysis follows, in general, that of Kiene \& Gerard (1994); using titanium trichloride $\left(\mathrm{TiCl}_{3}\right)$ for the reduction of DMSO to DMS. The following changes were made to the Kiene \& Gerard (1994) protocol; $\mathrm{TiCl}_{3}$ (stabilized solution, Fisher Scientific) was heated to $50^{\circ} \mathrm{C}$ and bubbled with $\mathrm{N}_{2}$ for $2 \mathrm{~h}$, and all glassware was muffled overnight at $400^{\circ} \mathrm{C}$ and rinsed with $\mathrm{TiCl}_{3}$ prior to usage. $\mathrm{TiCl}_{3}$ was cooled to room temperature before $10 \mathrm{ml}$ was added to a $40 \mathrm{ml}$ seawater sample. The reaction vial was immediately closed and kept at $4{ }^{\circ} \mathrm{C}$ until analysis. Prior to analysis 
of the produced DMS, reaction vials were placed in a water bath at $50^{\circ} \mathrm{C}$ for $2 \mathrm{~h}$ to ensure full conversion of DMSO to DMS. After the heating step the vials were allowed to cool to room temperature. A glass syringe (rinsed with $\mathrm{TiCl}_{3}$ ) was used to draw subsamples of $4 \mathrm{ml}$ through the septum that sealed the reaction vial and to inject the sample into the sparger, which remained sealed with a septum.

DMS generated from base digestion of DMSP and reduction of DMSO was measured following the procedure described for DMS. However, one adaptation was made to analyze DMSO samples: after bubbling to strip DMS from the treated seawater, the gas passed a trap containing solid $\mathrm{Na}_{2} \mathrm{CO}_{3}$ in order to neutralize acids before concentration onto Tenax and subsequent desorption into the gas chromatograph.

The GC was calibrated with standards prepared by injecting a sample of DMS from a calibrated permeation tube. Standards for DMS (Sigma Aldrich) were prepared in methanol. DMSO standards were made in $20 \% \mathrm{TiCl}_{3}$ (diluted with Milli-Q water). The diluted $\mathrm{TiCl}_{3}$ was heated to $50^{\circ} \mathrm{C}$ and bubbled with $\mathrm{N}_{2}$ for $2 \mathrm{~h}$ prior to use to prevent contamination with DMSO. Subsequently, the $\mathrm{TiCl}_{3}$ solution and $99.9 \%$ DMSO (Fisher Scientific) were cooled to $4^{\circ} \mathrm{C}$ before dilution into a working stock. Reaction vials were immediately sealed with a Teflon septum and stored at $4^{\circ} \mathrm{C}$ until usage (within 1 wk of preparation). Cooling to $4^{\circ} \mathrm{C}$ slowed the reduction of DMSO: $>72 \mathrm{~h}$ were required before $60 \%$ of the total DMSO was reduced. Prior to analysis the standards were heated to $50^{\circ} \mathrm{C}$ for $2 \mathrm{~h}$. Comparison of standards directly analyzed after addition of $\mathrm{TiCl}_{3}$ and standards stored for $1 \mathrm{wk}$ after addition did not reveal a significant difference between the treatments $(n=12$, p < 0.05). Replicate standards agreed to within $15 \%$, which indicates that the loss of DMS due to immediate reaction of DMSO with $\mathrm{TiCl}_{3}$ was small. We did not test what the effect of temperatures higher than $4^{\circ} \mathrm{C}$ would be on the reaction speed and reproducibility of standards and samples. However, Kiene \& Gerard (1994) indicate that the conversion of DMSO to DMS at room temperature is very slow, which suggests that it is feasible to work at room temperature.

Bacterial numbers. Subsamples of $4.5 \mathrm{ml}$ were taken from the $4.4 \mathrm{l}$ seawater samples and immediately fixed by $1 \%$ (final conc.) formaldehyde and stored at $4^{\circ} \mathrm{C}$ in the dark until analyses (within $24 \mathrm{~h}$ ). For bacterial counts, a volume of $1 \mathrm{ml}$ was incubated for 5 min with $4 \mu \mathrm{l}$ Acridine Orange (final conc. $0.01 \%$ ) and subsequently filtered onto black $0.2 \mu \mathrm{m}$ Nuclepore filters (Hobbie et al. 1977). After staining, cell numbers were immediately counted on a Zeiss epifluorescence microscope.

DMS, major sulfur compounds and bacterial numbers were analyzed in triplicate; replicability of the sulfur compound counts was within 5 and $10 \%$ respectively.

\section{RESULTS AND DISCUSSION}

\section{Skimmer artifact}

Comparison of water sampled through the stainless tubing with bulk water of the aquarium showed no significant loss of DMS through the tubing $(\mathrm{n}=7, \mathrm{p}<$ $0.05)$. Hence, the ratio between DMS in the water collected through the stainless tubing and DMS in water collected by the skimmer represents the loss of DMS relative to the concentration in the aquarium. Testing at different wind speeds showed a significant loss of about $50 \%$ of the DMS at a wind speed of $0 \mathrm{~m} \mathrm{~s}^{-1}$ ( $\mathrm{n}=10, \mathrm{p}<0.05$; note that the rotation of the skimmer creates air movement even when the ventilator is switched off). The loss increased with increasing wind speed, but seemed to reach a maximum of $70 \%$ at a wind speed of $2 \mathrm{~m} \mathrm{~s}^{-1}$ (Table 1). This shows that although the handling time between collection of the surface sample and storage in the first collection reservoir was very short $(1.5 \mathrm{~s})$, a significant loss of DMS occurred $(n=10, p<0.05)$. Tests with the more soluble gas $\mathrm{CS}_{2}$ showed a similar effect: significant losses of $\mathrm{CS}_{2}$ with increasing wind speed $(\mathrm{n}=10, \mathrm{p}<0.05)$, although the effect was less pronounced (Table 1). A comparison between screen and skimmer collections was not within the scope of this study, but the above results suggest that the use of screens would also lead to a significant loss of volatile compounds. It is very likely that this would exceed the loss observed with the skimmer, since the handling time to transfer the samples from the screen to flasks is probably longer than $1.5 \mathrm{~s}$.

While a significant loss of volatile compounds occurred on the surface of the skimmer there was apparently no loss of Escherichia coli cells ( $\mathrm{n}=10, \mathrm{p}<0.05$; Table 1). It is therefore assumed that the skimmer accurately collects bacteria and other small particles.

Although microlayer sampling for non-volatile species such as DMSP and DMSO and bacteria might be valid, some consideration should be given to potential artifacts. Delicate phytoplankton and possibly micro-

Table 1. Percentage loss (-), or gain (+), of DMS, $\mathrm{CS}_{2}$ and bacteria during collection of water samples by skimmer at different wind speeds determined by comparison of skimmer data with those from water samples collected by stainless steel tubing in vicinity of rotating cylinder of the skimmer

\begin{tabular}{|lccc|}
\hline $\begin{array}{l}\text { Wind speed } \\
\left(\mathrm{m} \mathrm{s}^{-1}\right)\end{array}$ & DMS & $\mathrm{CS}_{2}$ & Cell no. \\
\hline 0 & -48 & -24 & -4 \\
1 & -57 & -42 & +1 \\
2 & -70 & -57 & +3 \\
3 & -71 & -56 & -2 \\
\hline
\end{tabular}


zooplankton, are known to burst when exposed to air (Goldman \& Dennet 1985). Susceptibility of some marine phytoplankton species to cell breakage during sampling on a thin film sampler is likely to occur. Such an artifact could affect the partitioning between dissolved and particulate pools of DMSP and DMSO in samples collected at the sea surface. It was therefore decided to present total values of DMSP and DMSO in this study.

\section{Meteorology}

Conditions during the 5 sampling periods varied (Fig. 1, Table 2). Wind speed $(U)$ ranged from 2.5 to $5.5 \mathrm{~m} \mathrm{~s}^{-1}$; resulting in smooth $\left(U \leq 3.6 \mathrm{~m} \mathrm{~s}^{-1}\right)$ to rough $\left(3.6 \mathrm{~m} \mathrm{~s}^{-1}<U \leq 13 \mathrm{~m} \mathrm{~s}^{-1}\right)$ regimes of the water surface (defined as a function of wind speed by Liss \& Merlivat 1986). The 14 and 18 August experienced equal meteorological conditions with wind speed around $5 \mathrm{~m} \mathrm{~s}^{-1}$ and an average wave height of about $0.47 \mathrm{~m}$. Low wind speed $\left(3 \mathrm{~m} \mathrm{~s}^{-1}\right)$ and smooth surface conditions (wave height $0.2 \mathrm{~m}$ ) experienced on 15 August. Sea surface roughness on 25 August was comparable to the sea state on 15 August, despite a relatively high wind speed of $5 \mathrm{~m} \mathrm{~s}^{-1}$. The strong wind on 25 August resulted in rough conditions the next day (26 August), with an average wave height of $0.6 \mathrm{~m}$ and a wind speed of $\sim 2.7 \mathrm{~m} \mathrm{~s}^{-1}$. This indicates that there is no relation between surface roughness and averaged wind speed: wave height is the result of a longer wind history than the $2 \mathrm{~h}$ averaging period.

Air and water temperatures (Fig. 1B) varied around 24.7 and $19.3^{\circ} \mathrm{C}$ respectively, indicating that atmospheric conditions were stable during the sampling period and that turbulence (controlling the rate of gas transport in the atmosphere) was a result of friction between the ocean and the wind rather than the result of buoyancy. The lowest air and water temperatures were measured on 25 August, a day with low incoming solar radiation $\left(244 \mathrm{~W} \mathrm{~m}^{-2}\right)$ compared to conditions on other days during the sampling period $\left(\sim 700 \mathrm{~W} \mathrm{~m}^{-2}\right.$, Fig. 1C).

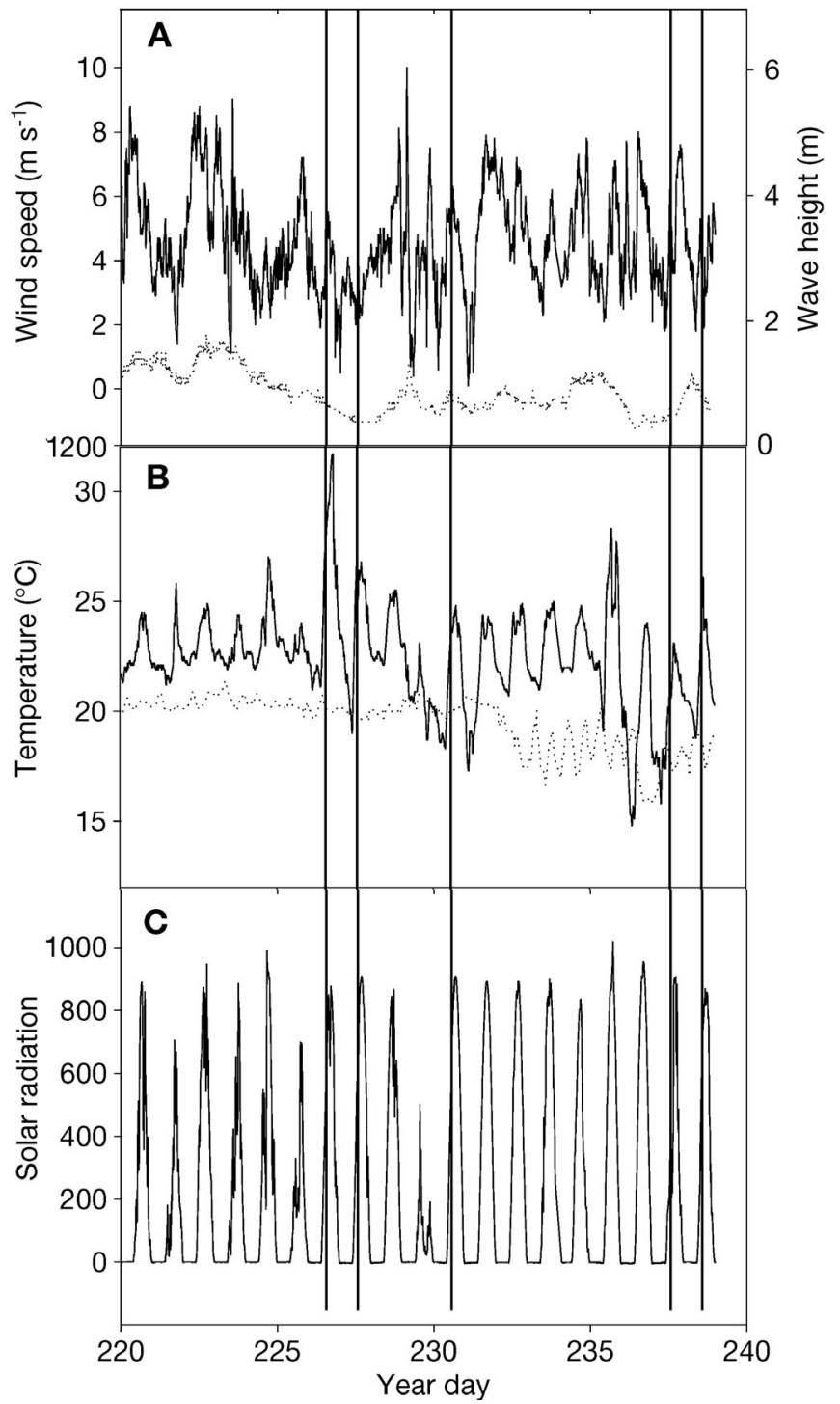

Fig. 1. Sea state and meteorology derived from the Martha's Vineyard Coastal Observatory from Year Day 220 to 240 (GMT) (see 'Results and discussion' for details). (A) Wind speed (continuous line) and wave height (dotted line); (B) air temperature (continuous line) and water temperature (dotted line); (C) solar radiation. Vertical lines: sampling periods

Table 2. Wave height, meteorology, and gradients of DMS from 10 to $500 \mathrm{~cm}$ depth and DMSP and DMSO from surface to $10 \mathrm{~cm}$ depth in August 2003. Minus sign indicates decrease towards surface. * Significant gradient $(n=6, p<0.05)$

\begin{tabular}{|c|c|c|c|c|c|c|c|c|}
\hline \multirow[t]{2}{*}{ Date } & \multirow{2}{*}{$\begin{array}{l}\text { Wave height } \\
\text { (m) }\end{array}$} & \multirow{2}{*}{$\begin{array}{l}\text { Wind speed } \\
\qquad\left(\mathrm{m} \mathrm{s}^{-1}\right)\end{array}$} & \multicolumn{2}{|c|}{$-T\left({ }^{\circ} \mathrm{C}\right)-$} & \multirow{2}{*}{$\begin{array}{l}\text { Solar radiation } \\
\qquad\left(\mathrm{W} \mathrm{m}^{-2}\right)\end{array}$} & \multicolumn{3}{|c|}{$\longrightarrow$ Gradients $\left(\mathrm{pM} \mathrm{cm}^{-1}\right)$} \\
\hline & & & Air & Water & & DMS & Total DMSP & Total DMSO \\
\hline 14 & 0.45 & 4.83 & 28.3 & 20.1 & 703 & $-20^{*}$ & 310 & 50 \\
\hline 15 & 0.2 & 3.05 & 25.9 & 19.7 & 674 & -3 & $1020^{*}$ & $390^{*}$ \\
\hline 18 & 0.48 & 5.5 & 23.7 & 20.1 & 719 & $-6^{*}$ & -60 & 60 \\
\hline 25 & 0.3 & 5.03 & 20.9 & 17.8 & 244 & $-5^{*}$ & $600^{*}$ & 110 \\
\hline 26 & 0.6 & 2.65 & 24.9 & 18.8 & 700 & $-10^{*}$ & 40 & 30 \\
\hline
\end{tabular}


Based on the study of Kieber et al. (1996), it can be predicted that atmospheric ventilation is the dominant removal pathway of DMS in the upper $1 \mathrm{~m}$ of the water column. However, at wind speeds of $5.6 \mathrm{~m} \mathrm{~s}^{-1}$ (the lowest wind speed met during the study of Kieber et al. 1996), turnover rates of DMS due to photolysis were comparable to the atmospheric flux. In our study, stratification of the water column would be most pronounced on 15 August, a day characterized by low wind speeds, smooth surface conditions, and high incoming radiation. Calm conditions would suppress the efflux of DMS, and consequently small windgenerated gradients of DMS would be expected on 15 August. However, mixing of deeper water is correspondingly lower and, in addition, high incoming radiation during smooth conditions increases photochemistry at the surface. Both processes tend to maintain a gradient towards the surface.

\section{DMS}

Concentrations around MVCO (Fig. 2) varied from $17 \mathrm{nM}$ at $500 \mathrm{~cm}$ depth on 14 August to $2.56 \mathrm{nM}$ at $10 \mathrm{~cm}$ depth on 25 August. DMS concentrations also varied from day to day; e.g. there was an almost 3-fold increase in DMS concentrations at $10 \mathrm{~cm}$ depth from 14 to 15 August and a similar increase at $500 \mathrm{~cm}$ depth from 25 to 26 August. The observed variability of DMS is common in coastal areas and is linked to the occur-

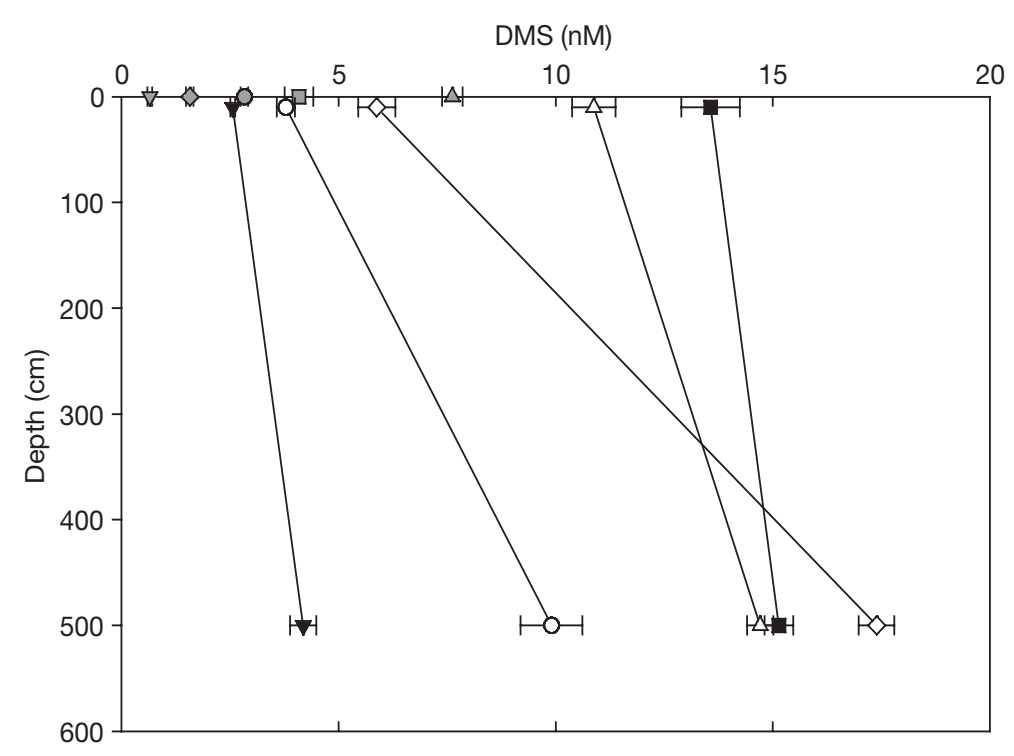

Fig. 2. Near surface DMS concentrations on $14(\diamond), 15(\mathbf{\square}), 18(\Delta)$, $25(\mathbf{\nabla})$ and $26(\mathrm{O})$ August 2003. $(\boldsymbol{\square}, \mathbf{\nabla})$ Data obtained during smooth surface conditions with wave heights of $\leq 0.3 \mathrm{~m}$. Surface-layer data (gray symbols) were erroneous due to evaporation of DMS from surface skimmer. Data are means $\pm 1 \mathrm{SD}(\mathrm{n}=3)$ rence of different water masses along the coast and short-term changes in bacterial and phytoplankton communities and foodweb dynamics. DMS concentrations in the water column are determined by the enzymatic conversion of DMSP to DMS by DMSP-lyase, bacterial consumption, photo-oxidation and efflux to the atmosphere. Biological consumption may be the most important removal pathway for DMS when the whole mixed layer is considered (Kieber et al. 1996).

Although Fig. 2 shows DMS concentrations in the microlayer samples, it has to be emphasized that these values were influenced by the loss of DMS from the thin water film on the skimmer. Surface DMS values will not be discussed further. DMS gradients from 10 to $500 \mathrm{~cm}$ varied from 3 to $20 \mathrm{pM} \mathrm{cm}^{-1}$ (Table 2), i.e. with lower values towards the sea surface. Hence, the decrease in DMS between 500 and $10 \mathrm{~cm}$ varied between 66 and $10 \%$.

Gradients of DMS from 10 to $500 \mathrm{~cm}$ show a weaker dependence with 2 h-averaged wind speed (Fig. 3A) than with wave height (Fig. 3B, generalized linear Model, $\mathrm{R}^{2}=0.013$ and $\mathrm{R}^{2}=0.43$ respectively, $\left.\mathrm{p}<0.05\right)$. Waves reflect the wind history and it is therefore not surprising to find some dependence between wave height and steepness of the DMS gradients. The data set is, however, too limited to derive a relationship between DMS gradient and wave height.

The gradient depends not only on outgassing but also on mixing of the water column. It is therefore surprising to find such large gradients in relatively rough conditions such as those encountered on 14 and $26 \mathrm{Au}-$ gust 2003, when wave height was 0.45 and $0.6 \mathrm{~m}$, respectively. A similar sea state, with an average wind speed of $5.5 \mathrm{~m} \mathrm{~s}^{-1}$ and an average wave height of $0.48 \mathrm{~cm}$, occurred on 18 August, when a much smaller DMS gradient was found. Measurement of underwater turbulence would give insight into the question as to whether the gradient is a result of outgassing or is largely the effect of patchiness in the water column, with different characteristics at different depths. Such measurements were not made, but the vertical distribution of DMSP, DMSO and bacteria can be used as an indication of turbulence in the water column: evenly distributed DMSP, DMSO and cell numbers would indicate a well-mixed water column.

Commonly used gas exchange models (e.g. Kettle \& Andreae 2000) rely on the assumption that the flux $(F)$ of a gas across the air-water interface is the product of the air-water concentration disequilibrium $(\Delta C)$ and a kinetic parameter, the transfer velocity $\left(k_{\text {gas }}\right)$, which quantifies the rate at which the gas crosses the air-sea interface: $F=k_{\text {gas }} \Delta C$. Usually $\Delta C$ is derived from water sampled at some depth from the surface but, clearly, 


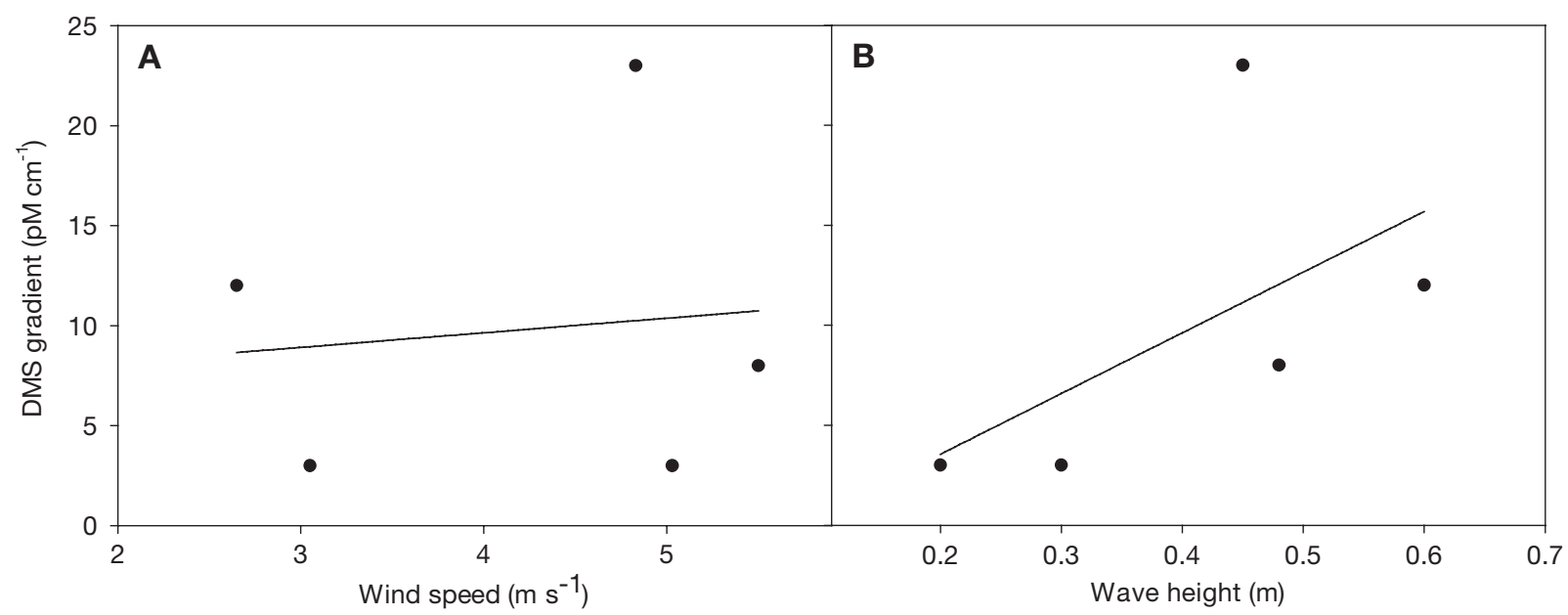

Fig. 3. DMS gradients between 10 and $500 \mathrm{~cm}$ depth as a function of (A) wind speed and (B) wave height. Lines are linear regressions; generalized linear model, $p<0.05(n=5)$ : $(A) R^{2}=0.013$, (B) $R^{2}=0.43$

the results show that gradients should be taken into account to calculate $\Delta C$ and the subsequent derivation of fluxes. Gradients should also be considered when transfer velocities are derived from direct measurement of the flux and the subsequent determination of $k_{\text {gas }}$ by using $k_{\text {gas }}=F / \Delta C$.

However, studies that focused on DMS gradients towards the microlayer are rare. The few papers that have been published on this topic reveal that the gradients can be either positive (with high DMS concentrations towards the sea surface) or negative. Turner \& Liss (1985) found an increase in DMS at the sea surface during phytoplankton blooms, but a decrease during non-bloom conditions. DMS enrichment of the surface microlayer was also found by Nguyen et al. (1978) and more recently by Yang (1999), while Andreae et al. (1983) did not find any gradient towards the sea surface. However, most of these authors mentioned significant artifacts involved with the sampling method, e.g. Yang et al. (2001) mention the loss of DMS from screens and glass plates due to outgassing. Other techniques that allow accumulation of samples without exposure to the atmosphere (and loss of volatile compounds) are needed to attain more insight into the biochemistry of the sea surface.

\section{DMSP}

Total DMSP concentrations varied between and 35 and 60 nM (Fig. 4), with low concentrations on 14 August and higher concentrations on 25 August. As observed with DMS, concentrations of DMSP change considerably on a day-to-day basis. For example, values increased by $25 \%$ from 14 to 15 August, and a similar decrease occurred from 25 to 26 August.

There was no apparent gradient on 14, 18 and $26 \mathrm{Au}-$ gust, when sea surface conditions were relatively rough (Table 2). This suggests that the water column was wellmixed and that the DMS profiles observed on these days (Fig. 2) were a result of emission to the atmosphere. Gradients were larger during calm conditions on 15 and 25 August, with an increase in DMSP at the sea surface.

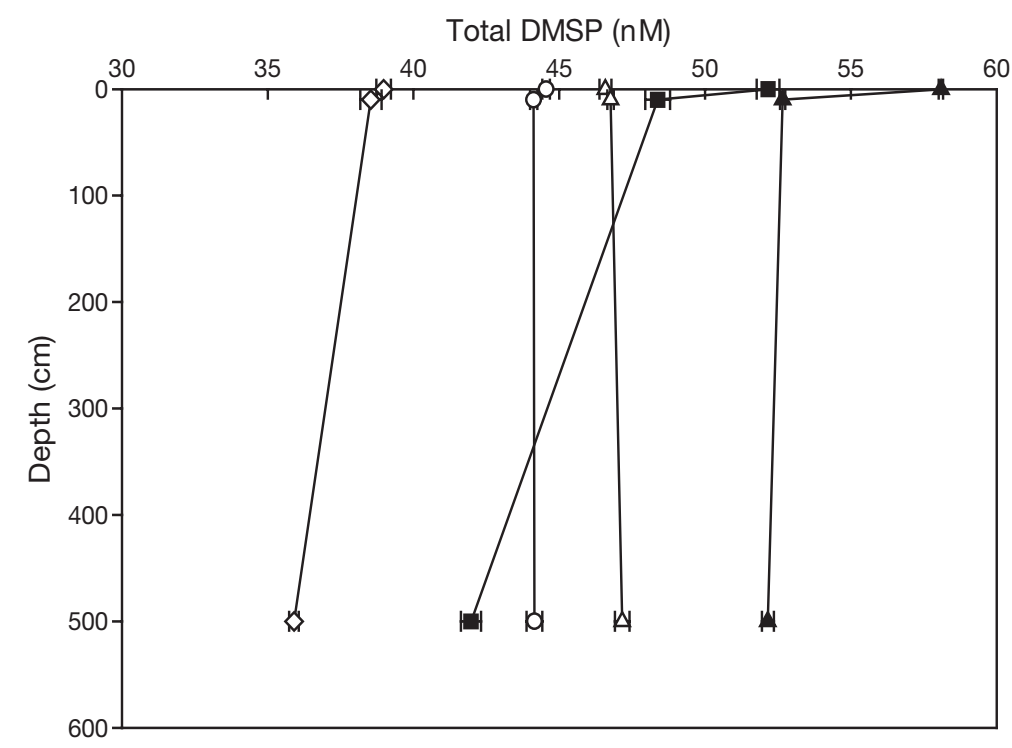

Fig. 4. Subsurface concentrations of total DMSP on $14(\diamond), 15(\mathbf{\square}), 18(\Delta)$, $25(\mathbf{\Delta})$, and $26(\mathrm{O})$ August 2003. ( $\mathbf{\square}, \mathbf{\Delta})$ Data obtained during smooth surface conditions with wave heights of $\leq 0.3 \mathrm{~m}$. Data are means $\pm 1 \mathrm{SD}(\mathrm{n}=3)$ 


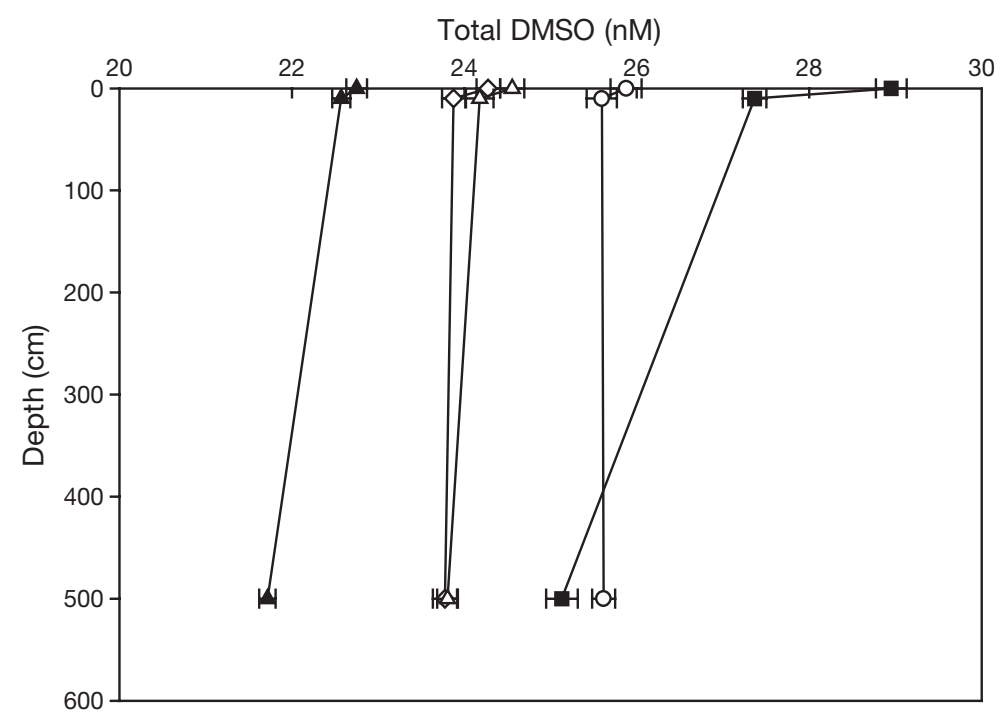

Fig. 5. Subsurface concentrations of total DMSO on $14(\diamond), 15(\mathbf{\square})$, $18(\Delta), 25(\Delta)$, and $26($ () August 2003. Further details as for Fig. 4

Recently Sunda et al. (2002) proposed that DMSP and its breakdown products (amongst which are DMS and DMSO) function as part of a high-capacity cellular antioxidant system that readily scavenges hydroxyl radicals and other reactive oxygen species. Exposure to high levels of oxidative stressors such as solar ultraviolet radiation occurs during calm conditions, when stratification traps some part of the plankton community near the surface. Under such conditions (as on 15 and 25 August), photo-effects could become important for the DMS pool, resulting in oxidation of DMS, accumulation of DMSP in algal cells, and/or extra lyses of DMSP to DMS. Our study could indicate a response by algae towards accumulation of DMSP, due to increased oxidative stress during smooth sea surface conditions.

\section{DMSO}

The biochemistry of DMSO is less well understood than the biochemical cycle of DMS and DMSP. DMS oxidation, either photochemically or by phototrophic bacteria, could lead to DMSO formation (Brimblecombe \& Shooter 1986). Simó et al. (1998) and Lee et al. (1999) established that phytoplankton can biosynthesize DMSO. Organisms could benefit from intracellular DMSO, which forms a good cryoprotectant and an efficient scavenger of free radicals. As for dissolved DMSP, the transformation of DMSO from the intracellular to dissolved phase occurs via cell senescence and grazing, but also via leakage from healthy cells. Little is known about the fate of dissolved DMSO. Some studies suggest that some bacteria that are able to consume DMS are also able to metabolize DMSO (e.g. Taylor \& Kiene 1989).

Total DMSO concentrations varied between 21 and $30 \mathrm{nM}$ (Fig. 5), with the highest concentrations on 15 August. Gradients (Fig. 5) showed an increase in DMSO to the surface, with strongest gradients on 15 August (Table 2). Although photooxidation may have been enhanced in the microlayer during calm days, photo-oxidation of DMS on the skimmer might also have occurred. However, DMSO gradients on 15 August were not only found in the top $10 \mathrm{~cm}$, but continued down $500 \mathrm{~cm}$ depth, indicating that the observed DMSO profile was not entirely a product of a sampling artifact. No obvious gradient was found on 25 August, a day with comparable surface conditions but low incoming radiation. Low photo-oxidation rates due to a decrease in incoming radiation on 25 August could explain the low DMSO concentrations on this (cloudy) day, although DMSO concentration on 18 August displayed similar values under conditions of high light intensity.

\section{Numbers of bacteria}

These varied between $1.37 \times 10^{6}$ and $1.6 \times 10^{6}$ cells ml $^{-1}$ (Fig. 6). Small gradients were found on 15 and 25 August, when total sea surface cell numbers increased

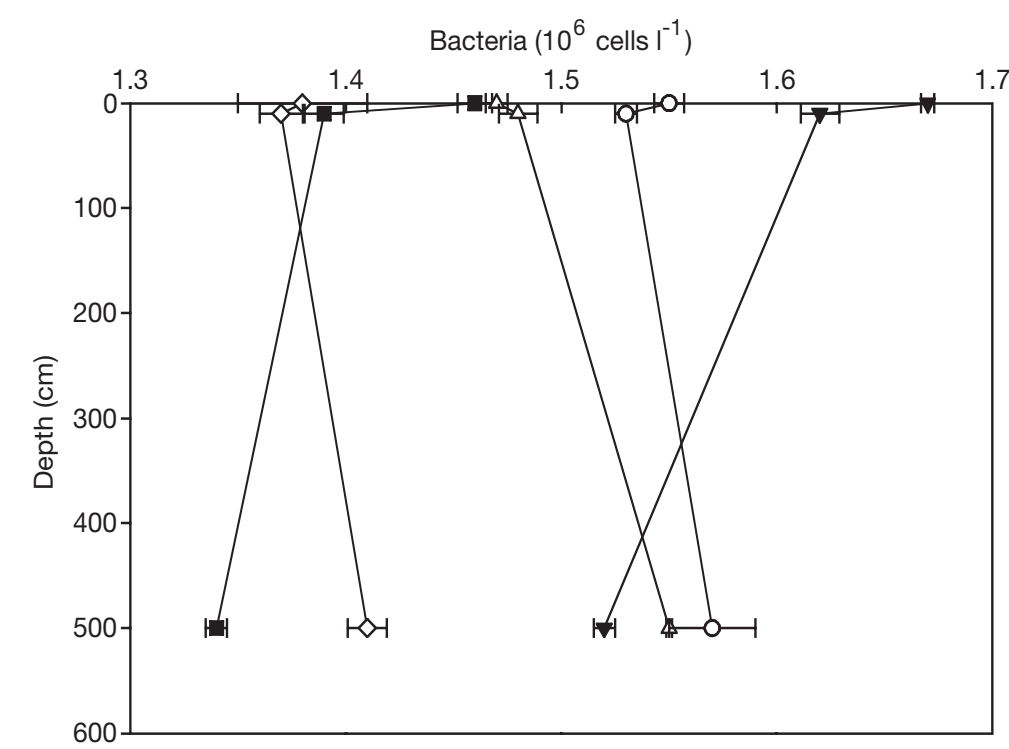

Fig. 6. Subsurface bacterial cell numbers on $14(\diamond), 15(\boldsymbol{\nabla}), 18(\Delta), 25(\boldsymbol{\nabla})$, and 26 (O) August 2003. Further details as for Fig. 4 
by about $10 \%$ compared to cell numbers at $500 \mathrm{~cm}$ depth. A $5 \%$ decrease was found on 18 August, and even smaller differences on the other days when sea surface conditions were relatively rough. The skimmer introduced an uncertainty of about $4 \%$ (Table 1) when tested with a culture of Escherichia coli. Hence, the gradients in the field are just slightly higher than the error margins of the skimmer.

Marine bacteria play a role in the transformation of DMS via consumption (Kiene 1993) and via DMS and non-DMS-producing degradation of DMSP (González et al. 1999, 2000, Kiene \& Linn 2000). Kieber et al. (1996) compared photochemical DMS removal to biological removal and loss via atmospheric ventilation in different layers of the euphotic zone. In most cases, biological removal exceeded the photochemical removal in the 0 to $1 \mathrm{~m}$ and 0 to $20 \mathrm{~m}$ surface layers. Because bacteria exert a controlling role on DMS concentration, it is important to improve our understanding of their role in the DMS cycle. We believe that the sampling technique described in this paper allows study of the link between DMSP, DMS and microbial foodweb structure and dynamics. A way to achieve this is to focus on correlations between the turnover of dissolved DMSP and total bacterial activity as a function of depth, and to allocate the abundance of DMS(P) utilizing bacteria in the water column.

\section{CONCLUSIONS}

Although the skimmer is not suitable for collecting samples of volatile compounds from the surface microlayer, samples taken at 10 and $500 \mathrm{~cm}$ depth did indicate a depletion of DMS towards the sea surface. Subsurface gradients were found on all sampling days with, on average, the largest gradients during rough sea surface conditions. The nearly uniform distribution of DMSP and bacterial cells during rough conditions indicates that the DMS gradients were a result of outgassing towards the atmosphere. The steep DMS gradients indicate that model-based estimation of fluxes from seawater DMS concentrations and data-based calculation of transfer velocities in conjunction with measured fluxes should be based on near surface concentrations, preferably surface microlayer values. However, sampling the surface microlayer without a significant loss of volatile compounds proves to be extremely difficult. The popular screen and drum techniques are likely to result in an underestimation of surface gas concentrations.

Elevated sea surface concentrations of DMSP and DMSO were found during calm surface conditions with high incoming solar radiation. However, increased microlayer concentrations of DMSP and DMSO might be an effect of increased oxidative stress and photooxidation on the surface of the collection drum. In addition, profiles of bacterial numbers showed an increase towards the sea surface at calm days.

This study provides circumstantial evidence that stratification of DMSP, DMSO and bacteria evolves during days with calm sea surface conditions. However, it cannot be excluded that the presented results are, at least to some extent, biased by an artifact introduced by the skimmer, even though these compounds are not subject to outgassing in the same way as DMS. Despite the short handling time between sampling and collection of the seawater into vials, vaporization and possibly also photo-oxidation occur on the drum. Other techniques that allow collection of samples near the air-water interface, without exposure to the atmosphere or sunlight are needed to provide more insight into the biogeochemistry at the sea surface.

Our results indicate that surface water conditions do influence concentrations of DMS, DMSP, DMSO and bacterial numbers at the sea surface. Surface water conditions probably influence conversion rates in surface films, and therefore the production of DMS and its release to the atmosphere. As oxidation of DMS to sulfuric acid in the atmosphere provides a major source of sulfate aerosols and cloud condensation nuclei (Andreae \& Crutzen 1997), an understanding of each and every aspect of biology and photochemistry in the surface layer is important.

Acknowledgements. The authors would like to thank skipper David Olmsted of RV 'Asterias', whose assistance in deployment and recovery was invaluable. We also thank the postdoctoral scholar program at the Woods Hole Oceanographic Institution, with funding provided by the J. Seward Johnson Fund. This work comprises WHOI contribution number 11248.

\section{LITERATURE CITED}

Andreae MO, Crutzen PJ (1997) Atmospheric aerosols: biogeochemical sources and role in atmospheric chemistry. Science 276:1052-1058

Andreae MO, Barnard WR, Ammons JM (1983) The biological production of dimethylsulfide in the ocean and its role in the global atmospheric sulfur budget. Ecol Bull 35: $167-177$

Ayers GP, Gillett RW (2000) DMS and its oxidation products in the remote marine atmosphere: implications for climate and atmospheric chemistry. J Sea Res 43:275-286

Brimblecombe P, Shooter D (1986) Photo-oxidation of dimethylsulphide in aqueous solution. Mar Chem 19:343-353

Carlson DJ, Canty JL, Cullen JJ (1998) Description of and results from a new surface microlayer sampling device. Deep-Sea Res 35:1205-1212

Charlson RJ, Lovelock JE, Andreae MO, Warren SG (1987) Oceanic phytoplankton, atmospheric sulfur, cloud albedo and climate. Nature 326:655-661

Frew MF, Nelson RK, McGillis WR, Edson JB, Bock EJ, Hara $\mathrm{T}$ (2002) Spatial variations in surface microlayer surfac- 
tants and their role in modulating air-sea exchange. Geophys Monogr 127:153-159

Glover DM, Frew NM, McCue SJ, Bock EJ (2002) A multi year time series of global gas transfer velocity from the TOPEX dual frequency, normalized radar backscatter algorithm. Geophys Monogr 127:325-332

Goldman JC, Dennet MR (1985). Susceptibility of some marine phytoplankton species to cell breakage during filtration and post filtration rinsing. J Exp Mar Biol Ecol 86:47-58

González JM, Kiene RP, Moran MA (1999) Transformation of sulfur by an abundant lineage of marine bacteria in the $\alpha$ subclass of the Proteobacteria. Appl Environ Microbiol 65:3810-3819

González JM, Simó R, Massana R, Covert JS, Casamayor EO, Pedrós-Alió C, Moran MA (2000) Bacterial community structure associated with a dimethylsulfoniopropionateproducing North Atlantic algal bloom. Appl Environ Microbiol 66:4237-4246

Groene T (1995) Biogenic production and consumption of dimethylsulfide (DMS) and dimethylsulfoniopropionate (DMSP) in the marine epipelagic zone: a review. J Mar Syst 6:191-209

Hale MS, Mitchell JG (1997) Sea surface microlayer and bacterioneuston spreading dynamics. Mar Ecol Prog Ser 147: 269-276

Hintsa EJ, Dacey JWH, McGillis WR, Edson JB, Zappa CJ, Zemmelink HJ (2004) Sea-to-air fluxes from measurements of the atmospheric gradient of dimethylsulfide and comparison with simultaneous relaxed eddy accumulation measurements. J Geophys Res 109:C001617:1-7

Hobbie JE, Daley RJ, Jasper S (1977) Use of Nuclepore filters for counting bacteria by fluorescence microscopy. Appl Environ Microbiol 33:1225-1228

Jacobs CMJ, Kohsiek W, Oost WA (1999) Air-sea fluxes and transfer velocity of $\mathrm{CO}_{2}$ over the North Sea: results from ASGAMAGE. Tellus 51:629-641

Kettle AJ, Andreae MO (2000) Flux of dimethylsulfide from the oceans: a comparison of updated data sets and flux models. J Geophys Res 105:26793-26808

Kettle AJ, Andreae MO, Amouroux D, Andreae TW and 28 others (1999) A global database of sea surface dimethylsulfide (DMS) measurements and a procedure to predict sea surface DMS as a function of latitude, longitude, and month. Global Biogeochem Cycles 13:399-444

Kieber DJ, Jianfu J, Kiene RP, Bates TS (1996) Impact of dimethylsulfide photochemistry on methyl sulfur cycling in the equatorial Pacific Ocean. J Geophys Res 101: 3715-3722

Kiene RP (1993) Microbial sources and sinks of methylated sulphur compounds in the marine environment. In: Murrell JC, Kelly DP (eds) Microbial growth on $\mathrm{C}_{1}$ compounds. Intercept, Andover, p 15-33

Kiene RP, Gerard G (1994) Determination of trace levels of dimethylsulfoxide (DMSO) in seawater and rainwater. Mar Chem 47:1-12

Kiene RP, Linn LJ (2000) Turnover of dissolved DMSP and its relationship with bacterial production in the Gulf of Mexico. Limnol Oceanogr 45:849-861

Kjelleberg S, Stenström ST, Odham G (1979) Comparative study of different hydrophobic devices for sampling lipid surface films and adherent microorganisms. Mar Biol 53: $21-25$

Lee PA, de Mora SJ, Levasseur M (1999) A review of dimethylsulfoxide in aquatic environments. Atmos-Ocean 37:439-456

Liss PS, Merlivat L (1986) Air-sea gas exchange rates: intro- duction and synthesis. In: Buat-Ménard P (ed) The role of air-sea exchange in geochemical cycling. D Reidel, Boston, p 113-129

Lovelock JE, Maggs RJ, Rasmussen RA (1972) Atmospheric dimethyl sulfide and the natural sulfur cycle. Nature 237: $452-453$

McGillis WR, Edson JB, Hare JE, Fairall CW (2001) Direct covariance air-sea $\mathrm{CO}_{2}$ fluxes. J Geophys Res 106: 16729-16745

Nguyen BC, Gaudry A, Bonsang B, Lambert G (1978) Reevaluation of the role of dimethyl sulfide in the sulphur budget. Nature 275:637-639

Plusquellec A, Beucher M, Lelay C, LeGal Y, Clerett JJ (1999) Quantitative and qualitative bacteriology of the marine water surface microlayer in a sewage polluted area. Mar Environ Res 31:227-239

Sciare J, Mihalopoulos N, Dentener FJ (2000) Interannual variability of atmospheric dimethylsulfide in the southern Indian Ocean. J Geophys Res 105:26369-26377

Shaw GE (1983) Bio-controlled thermostatis involving the sulfur cycle. Clim Change 5:297-303

Simó R, Hatton AD, Malin G, Liss PS (1998) Particulate dimethylsulfoxide in seawater: production by microplankton. Mar Ecol Prog Ser 167:291-296

Stefels J (2000) Physiological aspects of the production and conversion of DMSP in marine algae and higher plants. J Sea Res 43:183-199

Sunda W, Kieber DJ, Kiene RP, Huntsman S (2002) An antioxidant function for DMSP and DMS in marine algae. Nature 418:317-320

Taylor BF, Kiene RP (1989) Microbial metabolism of dimethyl sulfide. In: Saltzman ES, Cooper WJ (eds) Biogenic sulfur in the environment. ACS Symposium Series 393. American Chemical Society, Washington, DC, p 404-423

Turner SM, Liss PS (1985) Measurements of various sulphur gases in a coastal marine environment. J Atmos Chem 2: $223-232$

Wanninkhof R, McGillis WR (1999) A cubic relationship between air-sea $\mathrm{CO}_{2}$ exchange and wind speed. Geophys Res Lett 26:1889-1892

Yang GP (1999) Dimethylsulfide enrichment in the surface microlayer of the South China Sea. Mar Chem 66:215-224

Yang GP, Watanabe S, Tsunogai S (2001) Distribution and cycling of dimethylsulfide in surface microlayer and subsurface seawater. Mar Chem 76:137-153

Zemmelink HJ, Gieskes WWC, Klaassen W, de Baar HWJ, Dacey JWH, Hintsa EJ, McGillis WR (2002) Simultaneous use of relaxed eddy accumulation and gradient flux techniques for the measurement of sea-to-air exchange of dimethylsulfide. Atmos Environ 36:5709-5717

Zemmelink HJ, Gieskes WWC, Klaassen W, Beukema WJ and 5 others (2004a) Relaxed eddy accumulation measurements of the sea-to-air transfer of dimethylsulfide over the northeastern Pacific. J Geophys Res 109:C01025:1-10

Zemmelink HJ, Gieskes WWC, Klaassen W, de Groot HW, de Baar HJW, Dacey JWH, Hintsa EJ, McGillis WR (2004b) Air-sea gas transfer rates derived from atmospheric dimethyl sulphide fluxes. J Geophys Res 109:C08510:1-8

Zhang Z, Liu L, Wu Z, Li J, Ding H (1998) Physicochemical studies of the sea surface microlayer. I. Thickness of the sea surface microlayer and its experimental determination. J Colloid Interface Sci 204:294-299

Zhang Z, Liu L, Liu C, Cai W (2003) Studies on the sea surface microlayer. II. The layer of sudden change of physical and chemical properties. J Colloid Interface Sci 204:148-159 